\title{
Heat Energy From Value-Added Sawdust Briquettes Of Albizia Zygia.
}

\author{
*Aina, 0.M., Adetogun, A.C. And Iyiola, K.A.
}

\begin{abstract}
Sawdust accumulation and disposal at the various sawmills have always created an environmental problem. From some sawmills along Eleweran, Abeokuta the sawdust of a major hardwood species, Albizia zygia was singled out and collected during conversion at the head rig. The sawdust collected in 30 livestock feed sacs were later transported to Celina Industries where they were densified into briquettes at a pressure of 2000MPa at $450^{\circ} \mathrm{C}$ and heat intensity of $300 \%$ for the production of heat energy and a comparative analysis of the physical properties between the sawdust briquettes and the solid wood of the same species were carried out. The results obtained showed that the briquettes produced using 100\% sawdust of Albizia zygia had a lower moisture content of $7.10 \%$ than the solid wood (23.76\%) of the same species. Also, the heat value and the percentage dry matter of the briquettes were $4.723 \mathrm{Kcal}^{1}$ and $92.90 \%$ respectively which were much higher than the values obtained for the heat value $\left(4.014 \mathrm{Kcal}^{-1}\right)$ and percentage dry matter (76.24\%) of the solid wood of the same species. It was concluded that stable briquettes with higher calorific value can be produced from the sawdust of Albizia zygia.
\end{abstract}

Keywords: Briquette, head rig, sawdust, sawmill.

\section{Introduction}

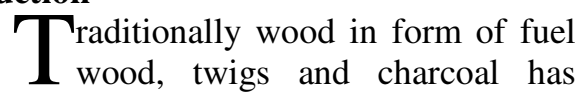
been the major source of renewable energy in Nigeria, accounting for $51 \%$ of the total energy consumption. The other sources of energy include natural gas $(5.2 \%)$, hydro electricity $(3.1 \%)$ and petroleum products $(41.3 \%)$ (Akinbami, 2001). The demand for fuel wood is expected to have risen to about $213.4 \times 10^{3}$ metric tones by the year 2030 (Adegbulugbe, 1994). The decreasing availability of fuel wood, coupled with the ever rising prices of kerosene and cooking gas in Nigeria, draw attention to the need to consider alternative sources of energy for domestic and cottage level industrial use in the country. Such energy sources should be renewable and should be accessible to the poor. As rightly noted by Stout and Best (2001), a transition to a sustainable energy system is urgently needed in the developing countries such as Nigeria. This should, of necessity be characterized by a departure from the present subsistence-level energy usage, levels based on decreasing firewood resources to a situation where human and farming activities would be based on sustainable and diversified energy forms.

An energy source that meets such sustainability requirements is fuel briquette. It produced at low cost and made conveniently assessable to firewood and charcoal for domestic cooking and agro-industrial operations, thereby reducing the high demand for both. Besides, briquettes have advantages over fuel wood in terms of greater heat intensity, cleanliness, convenience in use, and relatively smaller space requirement for storage (Singh and Singh, 1982; Wamukonya and Jenkins, 1995; Yaman et al., 2000; Olorunnisola, 2004). Briquetting can be done with or without binder. Doing it without the binder is more convenient but it requires sophisticated and costly presses and drying equipments which makes such processes unsuitable in a developing country like Nigeria. As observed by Wamukonya and Jenkins (1995), for briquetting industry to be successful in the less industrialized countries, the equipment should consist of locally designed simple, low-cost machines.

ial operations, thereby reducing the high demand for both. Besides, briquettes have advantages over fuel wood in terms of greater heat intensity, cleanliness, convenience in use, and relatively smaller space requirement for storage (Singh and Singh, 1982; Wamukonya and Jenkins, 1995; Yaman et al., 2000; Olorunnisola, 2004). Briquetting can be done with or without binder. Doing it without the binder is more convenient but it requires sophisticated and costly presses and drying equipments which makes such processes unsuitable in a developing country like Nigeria. As observed by Wamukonya and Jenkins (1995), for briquetting industry to be successful in the less industrialized countries, the equipment should consist of locally designed simple, low-cost machines.

In Nigeria, large quantities of agricultural and forestry residues produced

\footnotetext{
*Department of Forestry and Wildlife Management,College of Environmental Resources Management,University of
} Agriculture, Abeokuta, Nigeria. marcusaina@yahoo.com 
annually are vastly underutilized. The common practice is to burn these residues or leave them to decompose (Olorunnisola 1998, Jekayinfa and Omisakin 2005). However, previous studies have shown that these residues could vbe processed into upgraded liquid fuel products such as briquettes. A number of such locally available materials briquetted for fuel energy production include sawdust, cowpea chaff, corn cobs, and water hyacinth. Other studies had shown that, briquettes were produced with the aid of binders such as cassava starch and palm oil sludge, which tend to produce smoky briquettes. Waste paper also could be mixed with other biomass materials to produce relatively cheap and durable binderless briquettes. Attempts have also been made in the past to create fuel from newspaper by rolling them up into 'log'. However, it was found that the product did not burn well. Coconut husk, on the other hand, has a relatively high calorific value (between 18.1 and $20.8 \mathrm{MJ} / \mathrm{kg}$ ) coupled with relatively low ash content (3.5-6\%) (Jekayinfa and Omisakin, 2005).

The utilization of sawdust by converting it into heat is economically justified. The calorific value of sawdust briquettes is comparable to that of lower quality class coal. The idea of producing briquettes from fine timber wastes dates back to the turn of $19^{\text {th }}$ and $20^{\text {th }}$ centuries. The increasing demand for alternative energy sources makes the production of binder less briquettes essential.

\section{Materials and Methods}

Raw Materials Preparation: The sawdust of Albizia zygia was selectively collected from sawmills around Obantoko and Camp areas of Abeokuta in Ogun State. Fifteen bags of this sawdust was transported to a fire briquette producing firm in Ota named Celina Industries Limited. The moisture content (MC) of the sawdust before briquetting was $15 \%$.

\section{Briquetting Production and Quality} Evaluation: The sawdust is poured into a flash dryer which automatically reduce the moisture content to $5 \%$ at $250-300^{\circ} \mathrm{C}$ for 50 minutes. The sawdust is fed into the feeding bunker, an input tank through which dried sawdust is deposited into the screw briquetting plant. The conveyor carries sawdust into the tunnel where the suction blower absorbs heat from the oven to blow it. The cyclone separates hot air from the sawdust coming from the bin bunker. Briquettes are extruded as the briquette extruder squeeze sawdust at
$2000 \mathrm{~Pa}$ at $450^{\circ} \mathrm{C}$ and heat intensity of $300 \%$. The process lasted for 40 minutes.

Data Collection: The length, mass, inner and outer diameters of the briquettes were determined. These measurements were used to compute the volume and density of each of the fifty briquettes produced.

Data were also collected on the physical properties of the solid wood and the briquettes produced from Albizia zygia sawdust. The methods used are given below.

(a) Moisture Content: $5 \mathrm{~g}$ of the sample was weighed into a previously weighed crucible. The crucible plus sample taken was then transferred into the oven set at $100^{\circ} \mathrm{C}$ to dry to a constant weight for 24 hours overnight. At the end of the 24 hours, the crucible plus sample was removed from the oven and transferred to a desiccator, cooled for ten minutes and weighed.

The formula:

$$
\% \text { Dry Matter }(\mathrm{DM})=\frac{\mathrm{w}_{3}-\mathrm{w}_{\mathrm{o}} \mathrm{x}}{\mathrm{w}_{1}-\mathrm{w}_{\mathrm{o}}} 100
$$

$\%$ Moisture $=\frac{\mathrm{w}_{1}-\mathrm{w}_{3} \times 100}{\mathrm{w}_{1}-\mathrm{w}_{\mathrm{o}}}$

Or \% Moisture $=100-\%$ DM

Where, $\mathrm{W}_{\mathrm{o}}$ = weight of empty crucible $\mathrm{W}_{1}=$ weight of crucible plus sample

and dried sample.

$$
\mathrm{W}_{3}=\text { weight of crucible plus oven. - }
$$

(b) Density: Thee weights of briquettes were determined on the balanced in the laboratory. Then, the volumes of briquettes were determined by a simple calculation based on the direct measurement of length, width, and thickness of the briquettes.

Formula:

$\mathrm{D}\left(\mathrm{kg} / \mathrm{m}^{3}\right)=\mathrm{M} / \mathrm{V}$

Where,

$\mathrm{D}=$ Density

$\mathrm{M}=$ Mass

$\mathrm{V}=$ Volume

(c) Heat Value: The heat value of both samples was determined using a standard Gallenkamp Ballistic Bomb calorimeter. 0.50g of each samples of solid wood and briquette of Albizia zygia were weighed into the steel capsule. A $10 \mathrm{~cm}$ cotton thread was attached to the thermocouple to touch the capsule. The bomb was closed and charged in with oxygen up to 30 atm.

The bomb was fired up by depressing the ignite switch to burn the sample in an excess of oxygen. 
The maximum temperature rise in the bomb was measured with the thermocouple and galvanometer system

Formula

G.E. $(\mathrm{Kcal} / \mathrm{g})=\underline{\text { G.meter deflection } x \text { Calibration }}$

Weight of sample.

(d) Ash Content: $5 \mathrm{~g}$ of the briquette sample was weighed into a porcelain crucible. This was transferred into the muffle furnace set at $550^{\circ} \mathrm{C}$ and left for about 4 hours. About this time it had turned to white ash. The crucible and the content were cooled to about $100^{\circ} \mathrm{C}$ in air, then room temperature in a desiccator and weighed. This was done in duplicate and also replicated for thee solid wood of Albizia zygia. The formula for determining ash content is stated below.

$$
\begin{array}{r}
\text { Ash Content }=\underset{\text { Weight of ash }}{\text { Original weight of sample }} \\
\text { Pring }
\end{array}
$$

Data Analysis: Descriptive data statistical tools were used to describe the relationship between the physical properties of solid wood used for briquette and the briquette produced.

\section{RESULTS AND DISUSSION}

\section{Physical Characteristics of the Briquettes}

The production of briquette at Celina Industries is through the use of screw press briquetting machine, as shown in cross-section in Fig. 1. The outer surface of the briquette is carbonized and has a concentric hole at the centre. The average weight of the briquette is approximately $651 \mathrm{~g}$, while the average length and diameter are $15.5 \mathrm{~cm}$ and $5.1 \mathrm{~cm}$ respectively. The average volume is $609 \mathrm{~m}^{3}$ while the briquettes from $100 \%$ Albizia zygia sawdust assumed a brown coloration.

\section{Moisture Content}

It was observed in Table 2 that the briquette has lower moisture content than the wood produced from Albizia zygia. The quality of briquettes assessed on the basis of specific external features and certain physical parameter was very good. Their external surface was smooth and the structure of their cross-section was compact and homogenous. One of the main parameters determining briquette quality is moisture content of the sawdust used as the input material. The most durable briquettes of sawdust are of the moisture content of $5 \%$. The moisture content of the sawdust studied is 5\% which ensured production of good quality briquettes. This lower moisture content of briquettes implies higher calorific value.

The observed value of briquette (7.10) falls below the range of values (7.7-15.1\%, wet basis) reported by Wamukonya and Jenkins (1995) for sawdust and wheat straw briquettes, and the ranges of values (12-20\%, wet basis) recommended for good storability and combustibility of briquettes. Moisture content in excess of $20 \%$ would result in considerable loss of energy required for water evaporation during combustion at the expense of the calorific value of the fuel. Such a fuel may not also be stable in storage.

Heat Value

Heat value or calorific value determines the energy content of a fuel. It is the property of biomass fuel that depends on its chemical composition and moisture content. The most important fuel property is its calorific or heat value. Table 3 revealed that, briquettes made from Albizia zygia have a higher heat value than the solid wood of the same species. The briquettes generate more energy or heat per gram compared to the same amount of solid wood.

\section{Ash Content}

The briquettes of Albizia zygia have higher ash content than the solid wood of the same species. The lower moisture content increases combustion and invariably increasing the heat value. Briquette produced $92.90 \%$ dry matter while the wood had $76.24 \%$, dry matter thus having a reduced heat value (see Table 2). 


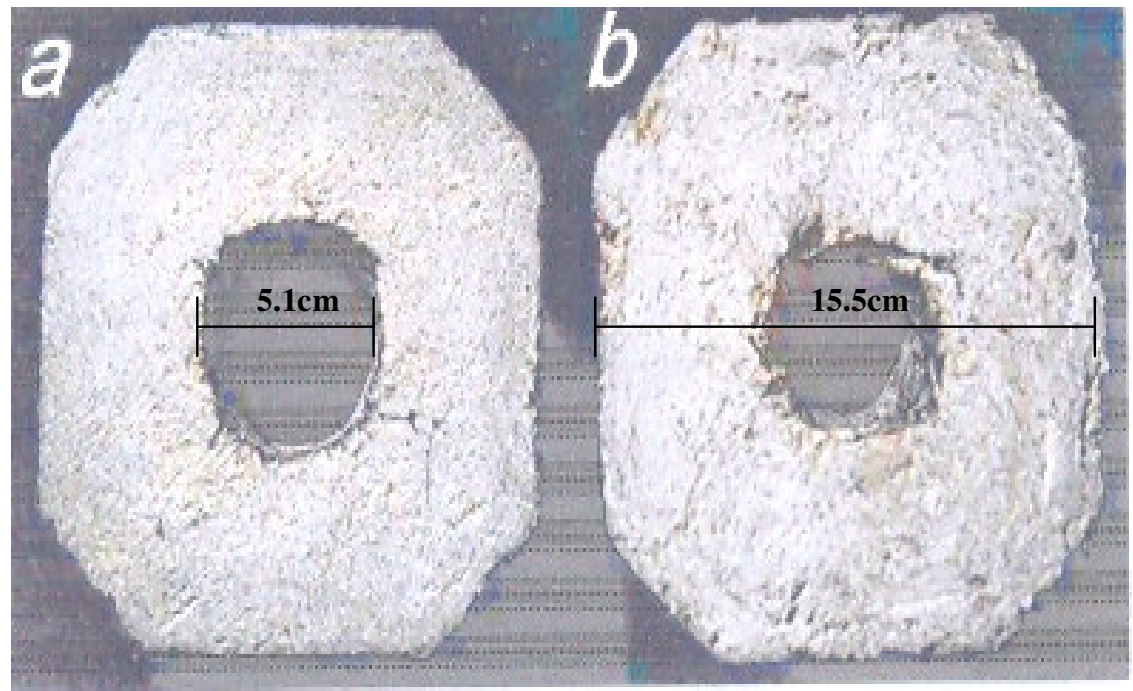

Fig. 1: The cross-sectional structure of a briquette

\section{Discussion}

The lignocellulose waste (sawdust) used for the production of briquettes was randomly collected from sawmills at Camp and Obantoko areas of Abeokuta in Ogun State. The sawdust of Albizia zygia was collected and transported to Celina Industries Limited, Ota Ogun State. The sawdust had a moisture content of $15 \%$. It was flash dried to reduce the moisture content automatically to $5 \%$ at a temperature of $250^{\circ} \mathrm{C}-300^{\circ} \mathrm{C}$ for 50 minutes. The quality of briquette is determined by the moisture content of the sawdust used as the input material. The higher the moisture content of the sawdust, the higher the loss of energy required for water evaporation during combustion at the expense of the calorific value of the briquette.

The dried sawdust was transferred into the screw press briquetting plant via the input tank (feeding bunker). The sawdust gets into the tunnel where heat is introduced by the suction blower. The sawdust passes through the bin bunker after which the cyclone separate hot air from the dried sawdust. Briquettes are continuously extruded when the briquette extruder squeezes sawdust at $2000 \mathrm{MPa}$ at a temperature of $450^{\circ} \mathrm{C}$ with heat intensity of $300 \%$. The entire process lasted for 40 minutes.
In determining the calorific value of the briquettes, the Gallenkhamp Bomb Calorimeter was first calibrated using a standard sample of Benzoic acid with a known calorific value of $6.32 \mathrm{kcalg}^{-1}$. A know mass of sample of small quantity, $0.5 \mathrm{~g}$ of the briquette was placed in the crucible. The sample was put inside an oven to ensure dryness. One end of a cotton thread strand with length $50 \mathrm{~mm}$ was inserted between the coil of ignition wire and the other end dipped into the centre of the sample in the crucible. The thread enhances the combustion of the sample inside the crucible. The bomb's body was placed and tightly screwed in position. The thermocouple wire was plugged into the bomb until the pressure rose to 25 bars. The light spot index was set to zero using the galvanometer zero knob ensuring a stable temperature before the firing knob was depressed and released to fire the bomb. Heat is released and the maximum deflection of the galvanometer scale was recorded after which the burnt gases were released from the apparatus with the aid of the pressure release valve.

The maximum deflection obtained in the galvanometer was converted to energy value of the briquette material by comparing the rise in galvanometer deflection with that obtained when a sample of known calorific 
value of benzoic acid is combusted. The process is repeated to determine the energy value of the solid wood sample of Albizia zygia. The energy values of both the wood and briquette samples of Albizia zygia is recorded in table 3.

\section{Conclusion}

In this study, it has been established that the briquettes manufactured from the sawdust of Albizia zygia has lower moisture content,

\section{References}

Adegbulugbe, A.O. (1994). Energyenvironmental issues in Nigeria. International Journal of Global Energy Issues 6 (12): 7 - 18. Akinbami, J.F.K. (2001). Renewable energy resources and technologies in Nigeria. Present situation, future prospects and policy framework. Mitigation and Adaptation strategies for Global Change 6: 155 - 181. Jekayinfa, S.O. and O.S. Omisakin (2005). The energy potentials of some agricultural wastes as local fuel materials in Nigeria. Agricultural Engineering International the CIGR E-Journal of Scientific Research and Development Vol., VII Manuscript E.E 05 003: 10Pp. Olorunnisola, A.O. (1998). The performance of sawdust briquettes combusted in a conventional coal stove. Nigeria Journal of Forestry. 28 (1): 15-18.

Olorunnisola, A.O. (2004). Briquetting of rattan furniture waste. Journal of Bamboo and higher calorific value and ash content than the fuel wood from the same species.

The experimental tests performed have also revealed that sawdust usually generated in large uncontrolled quantities can be converted into good quality, highly storable and durable high-grade solid fuel briquettes that will be suitable for both domestic and industrial energy production for heat generation.

Rattans 3(2): 139-149.

Singh, A. and Y. Singh (1982). Briquetting of paddy straw. Agricultural Mechanization in Asia, Africa and Latin America 42-44.

Stout, B.A. and G. Best (2001). Effective energy use and climate change: needs of rural areas in developing countries. Agricultural Engineering International: the CIGR E Journal of Scientific Research and Development Vol., 111, 19Pp.

Wamukonya, L. and B. Jenkins (1995). Durability and relaxation of sawdust and wheat-straw briquettes as possible fuels for Kenya. Biomass and Bioenergy 8(3): 175179.

Yousif, A.A. and A.E Abasaeed (2006). Experimental evaluation of a conical screw briquetting machine for the briquetting of carbonized cotton stalks in Sudan. Journal of Engineering and Sciences and Technology 1(2): 212-220. 
Table 1: Length, inner and outer diameter, mass and volume of each of the 50 units of briquettes.

\begin{tabular}{|c|c|c|c|c|c|c|c|c|}
\hline $\mathbf{S} / \mathbf{N}$ & $\begin{array}{l}\text { LENGTH } \\
(\mathrm{cm})\end{array}$ & $\begin{array}{l}\text { MASS } \\
\text { (g) }\end{array}$ & $\begin{array}{l}d_{1} \\
(\mathbf{c m})\end{array}$ & $\begin{array}{l}\mathbf{d}_{2} \\
(\mathbf{c m})\end{array}$ & $\begin{array}{l}D=d_{2}-d_{1} \\
(\mathrm{~cm})\end{array}$ & $\begin{array}{l}\mathrm{r}=\mathrm{d} / 2 \\
(\mathrm{~cm})\end{array}$ & $\begin{array}{l}\text { Volume } \\
\pi\left(d_{2}-d_{1}\right) h \\
\mathbf{c m}^{3}\end{array}$ & $\begin{array}{l}\text { Density } \\
\mathrm{m} / \mathrm{v} \\
\mathrm{Kg} / \mathrm{m}^{3}\end{array}$ \\
\hline 1 & 13.0 & 525 & 2.00 & 7.20 & 5.20 & 2.60 & 552.24 & 0.91 \\
\hline 2 & 12.5 & 550 & 2.00 & 7.20 & 5.20 & 2.60 & 530.99 & 1.04 \\
\hline 3 & 13.0 & 550 & 2.20 & 7.30 & 5.10 & 2.55 & 531.20 & 1.04 \\
\hline 4 & 13.0 & 550 & 2.20 & 7.40 & 5.20 & 2.60 & 552.24 & 0.99 \\
\hline 5 & 16.0 & 700 & 2.00 & 7.00 & 5.00 & 2.50 & 628.40 & 1.11 \\
\hline 6 & 12.0 & 525 & 2.10 & 7.20 & 5.20 & 2.60 & 530.99 & 0.98 \\
\hline 7 & 12.5 & 525 & 2.00 & 7.20 & 5.20 & 2.60 & 530.99 & 0.98 \\
\hline 8 & 14.0 & 550 & 2.00 & 7.00 & 5.00 & 2.50 & 510.57 & 1.03 \\
\hline 9 & 13.0 & 525 & 2.10 & 7.10 & 5.00 & 2.50 & 510.57 & 1.03 \\
\hline 10 & 12.5 & 525 & 2.00 & 7.00 & 5.00 & 2.50 & 490.93 & 1.07 \\
\hline 11. & 14.0 & 625 & 2.20 & 7.20 & 5.00 & 2.50 & 549.85 & 1.14 \\
\hline 12. & 13.0 & 675 & 2.00 & 7.30 & 5.30 & 2.65 & 573.68 & 1.18 \\
\hline 13. & 12.0 & 500 & 2.00 & 7.50 & 5.50 & 2.75 & 570.27 & 0.88 \\
\hline 14. & 16.0 & 625 & 2.00 & 7.40 & 5.40 & 2.70 & 732.97 & 0.85 \\
\hline 15. & 13.5 & 550 & 2.30 & 7.30 & 5.00 & 2.50 & 510.58 & 1.08 \\
\hline 16. & 14.5 & 650 & 2.10 & 7.40 & 5.30 & 2.65 & 639.88 & 1.02 \\
\hline 17. & 12.5 & 550 & 2.00 & 7.20 & 5.20 & 2.60 & 530.99 & 1.04 \\
\hline 18. & 16.5 & 675 & 2.10 & 7.10 & 5.00 & 2.50 & 648.04 & 1.04 \\
\hline 19. & 20.0 & 900 & 2.20 & 7.20 & 5.00 & 2.50 & 785.50 & 1.12 \\
\hline 20. & 11.0 & 525 & 2.00 & 7.30 & 5.30 & 2.65 & 485.42 & 1.08 \\
\hline
\end{tabular}




\begin{tabular}{|c|c|c|c|c|c|c|c|c|}
\hline $\mathbf{S} / \mathbf{N}$ & $\begin{array}{l}\text { LENGTH } \\
(\mathrm{cm})\end{array}$ & $\begin{array}{l}\text { MASS } \\
\text { (g) }\end{array}$ & $\begin{array}{l}d_{1} \\
(\mathrm{~cm})\end{array}$ & $\begin{array}{l}\mathbf{d}_{2} \\
(\mathbf{c m})\end{array}$ & $\begin{array}{l}D=d_{2}-d_{1} \\
(\mathrm{~cm})\end{array}$ & $\begin{array}{l}r=d / 2 \\
(\mathrm{~cm})\end{array}$ & $\begin{array}{l}\text { Volume } \\
\pi\left(d_{2}-d_{1}\right) h \\
\mathbf{c m}^{3}\end{array}$ & $\begin{array}{l}\text { Density } \mathrm{m} / \mathrm{v} \\
\mathrm{Kg} / \mathrm{m}^{3}\end{array}$ \\
\hline 21. & 14.0 & 575 & 2.10 & 7.30 & 5.20 & 2.60 & 594.72 & 0.97 \\
\hline 22. & 26.0 & 12.00 & 2.00 & 7.20 & 5.20 & 2.60 & 1104.48 & 1.09 \\
\hline 23. & 16.0 & 675 & 2.30 & 7.20 & 5.00 & 2.50 & 667.68 & 1.07 \\
\hline 24. & 17.0 & 750 & 2.00 & 7.00 & 5.00 & 2.50 & 667.68 & 1.12 \\
\hline 25. & 24.0 & 1050 & 2.20 & 7.40 & 5.20 & 2.60 & 1019.52 & 1.03 \\
\hline 26. & 22.0 & 975 & 2.20 & 7.40 & 5.20 & 2.60 & 434.56 & 1.04 \\
\hline 27. & 21.0 & 900 & 2.10 & 7.50 & 5.40 & 2.70 & 962.02 & 0.94 \\
\hline 28. & 19.0 & 800 & 2.20 & 7.40 & 5.20 & 2.60 & 807.12 & 0.99 \\
\hline 29. & 13.0 & 525 & 2.30 & 7.40 & 5.10 & 2.55 & 531.20 & 0.98 \\
\hline 30. & 14.0 & 500 & 2.00 & 7.00 & 5.00 & 2.50 & 549.85 & 0.91 \\
\hline 31. & 13.0 & 600 & 2.30 & 7.30 & 5.00 & 2.50 & 510.58 & 1.18 \\
\hline 32. & 19.0 & 650 & 2.00 & 7.00 & 5.00 & 2.50 & 746.23 & 0.87 \\
\hline 33. & 18.0 & 775 & 2.10 & 7.30 & 5.20 & 2.60 & 764.64 & 1.01 \\
\hline 34. & 20.0 & 875 & 2.00 & 7.00 & 5.00 & 2.50 & 785.5 & 1.11 \\
\hline 35. & 18.5 & 850 & 2.10 & 7.20 & 5.10 & 2.55 & 755.94 & 1.12 \\
\hline 36. & 18.0 & 700 & 2.20 & 7.20 & 5.00 & 2.50 & 706.95 & 0.99 \\
\hline 37. & 18.0 & 725 & 2.20 & 7.30 & 5.10 & 2.55 & 735.51 & 0.99 \\
\hline 38. & 16.0 & 675 & 2.00 & 7.40 & 5.40 & 2.70 & 732.97 & 0.92 \\
\hline 39. & 16.5 & 650 & 2.30 & 7.30 & 5.00 & 2.50 & 648.04 & 1.00 \\
\hline 40. & 16.0 & 670 & 2.00 & 7.40 & 5.40 & 2.70 & 732.97 & 0.91 \\
\hline 41. & 16.0 & 675 & 2.30 & 7.30 & 5.00 & 2.50 & 628.40 & 1.07 \\
\hline 42. & 16.5 & 575 & 2.30 & 7.40 & 5.10 & 2.55 & 674.20 & 0.85 \\
\hline
\end{tabular}




\begin{tabular}{|c|c|c|c|c|c|c|c|c|}
\hline $\mathbf{S} / \mathbf{N}$ & $\begin{array}{l}\text { LENGTH } \\
(\mathrm{cm})\end{array}$ & $\begin{array}{l}\text { MASS } \\
\text { (g) }\end{array}$ & $\begin{array}{l}\mathbf{d}_{1} \\
(\mathbf{c m})\end{array}$ & $\begin{array}{l}\mathbf{d}_{2} \\
(\mathrm{~cm})\end{array}$ & $\begin{array}{l}D=d_{2}-d_{1} \\
(\mathrm{~cm})\end{array}$ & $\mathrm{r}=\mathrm{d} / 2(\mathrm{~cm})$ & $\begin{array}{l}\text { Volume } \\
\pi\left(d_{2}-d_{1}\right) h \\
\mathbf{c m}^{3}\end{array}$ & $\begin{array}{l}\text { Density m/v } \\
\text { Kg/m }\end{array}$ \\
\hline 43. & 17.0 & 650 & 2.50 & 7.50 & 5.00 & 2.50 & 667.68 & 0.97 \\
\hline 44. & 16.0 & 700 & 2.30 & 7.50 & 5.20 & 2.60 & 679.68 & 1.03 \\
\hline 45. & 14.5 & 600 & 2.20 & 7.20 & 5.00 & 2.50 & 569.49 & 1.05 \\
\hline 46. & 11.0 & 475 & 2.20 & 7.20 & 5.00 & 2.50 & 432.03 & 1.09 \\
\hline 47. & 11.0 & 500 & 2.40 & 7.40 & 5.00 & 2.50 & 432.03 & 1.16 \\
\hline 48. & 12.0 & 500 & 2.00 & 7.00 & 5.00 & 2.50 & 471.30 & 1.06 \\
\hline 49. & 10.0 & 525 & 2.10 & 7.50 & 5.40 & 2.70 & 458.10 & 1.15 \\
\hline 50. & 9.5 & 450 & 2.40 & 7.40 & 5.00 & 2.50 & 373.11 & 1.20 \\
\hline$\Sigma$ & 776 & 32570 & 106.80 & 363.10 & 256.7 & 128.27 & 30494.25 & 51.48 \\
\hline$\overline{\bar{X}}$ & 15.52 & 651.4 & 2.14 & 7.26 & 5.13 & 2.56 & 609.88 & 1.03 \\
\hline
\end{tabular}

Source: Field Data, 2008.

Table 2: Moisture content and ash content (Dry matter) of solid wood and briquette of Albizia zygia

\begin{tabular}{|l|c|c|c|c|c|}
\hline Sample & Wt sample & $\begin{array}{l}\text { Dry matter + } \\
\text { wt empty can }\end{array}$ & Wt empty can & \% DM & \% MC \\
\hline Briquette & $5 \mathrm{~g}$ & 30.107 & 25.462 & 92.90 & 7.10 \\
\hline Wood & $5 \mathrm{~g}$ & 16.384 & 12.572 & 76.24 & 23.76 \\
\hline
\end{tabular}

Source: Field Data, 2008.

Table 3: Calorific value of briquette and solid wood of Albizia zygia.

\begin{tabular}{|l|l|l|l|l|l|}
\hline Sample & $\begin{array}{l}\text { Wt sample } \\
(\mathbf{g})\end{array}$ & $\begin{array}{l}\text { Calibration } \\
\text { constant }\end{array}$ & $\begin{array}{l}\text { Galvanometer } \\
\text { deflection }\end{array}$ & GE (kcal/g) & GE (kcal./kg) \\
\hline Briquette & 0.50 & 0.7872 & 3.0 & 4.7232 & 4723.02 \\
\hline Wood & 0.50 & 0.7872 & 2.55 & 4.0148 & 4014.80 \\
\hline
\end{tabular}

Source: Field Data, 2008. 